\title{
Contrasting responses of saproxylic insects to focal habitat resources: the example of longhorn beetles and hoverflies in Belgian deciduous forests
}

\author{
Philippe Fayt ${ }^{1, *}$, Marc Dufrêne ${ }^{1}$, Etienne Branquart $^{1}$, Pierre Hastir ${ }^{2}$, Christophe \\ Pontégnie $^{3}$, Jean-Marc Henin ${ }^{3}$ and Veerle Versteirt ${ }^{4}$ \\ ${ }^{1}$ Research Centre of Nature, Forests and Wood (CRNFB), Av. Maréchal Juin 23, B-5030 Gembloux, \\ Belgium; ${ }^{2}$ Biodiversity Research Centre, Catholic University Louvain (UCL), Croix du sud, 4-5, B-1348 \\ Louvain-La-Neuve, Belgium; ${ }^{3}$ Forest and Nature Management Unit, Gembloux Agricultural University \\ (FSAGX), Passage des Déportés 2, B-5030 Gembloux, Belgium; ${ }^{4}$ Department of Entomology, Royal Belgian \\ Institute of Natural Sciences (IRSNB), Vautierstraat 29, B-1000 Brussels, Belgium; *Author for \\ correspondence (e-mail: P.Fayt@mrw.wallonie.be; phone: +32-473-871-317; fax: +32-81-620-436)
}

Received 18 May 2005; accepted in revised form 20 October 2005

Key words: Cerambycidae, Flower resources, Microhabitat, Saproxylic, Syrphidae

\begin{abstract}
Although both saproxylic longhorn beetles and hoverflies benefit from the presence of woody substrates for reproduction, they differ in their requirements for floral resources and for microbiotopes of overmature and senescent trees. This led us to expect contrasting responses between the two species groups in relation to these essential resources. We examined this prediction in 22 mature oak- and beech-dominated stands of southern Belgium by relating their species assemblages to local vegetation structure and composition, altitude and landscape composition. Stands were organised in pairs as a function of their overall dead wood supply. Free-hanging window traps, stump emergence traps and Malaise traps produced 30 longhorn beetle species (1637 individuals) and 106 hoverfly species (3020 individuals). Paired-comparisons controlling for annual variation in captures showed that, unlike saproxylic hoverflies, stands with dead wood hosted more species and individuals of longhorn beetles. Accordingly, the two species groups were found to be independent on ordination axes, responding to different sets of environmental conditions. While stands dominated by oaks with a high snag volume were highly favoured by longhorn beetles, saproxylic and threatened syrphids were limited to open-stands with large trees and a well-developed, species rich herb layer providing the floral resources required for their reproduction. Our results suggest that, when defining criteria to identify or restore important habitats for saproxylic insect conservation, variables related to different aspects of dead wood supply should not be the only criteria taken into account.
\end{abstract}

\section{Introduction}

The study of factors underlying variability in the diversity of saproxylic organisms, those that depend upon woody substrates or upon the presence of other saproxylics for at least part of their life cycle (Speight 1989), has received growing attention during the last decades in the field of ecology, conservation biology, and forest management (Samuelsson et al. 1994; Grove 2002). This mainly stems from the findings that, besides representing a significant part of forest biodiversity (Siitonen 
2001), these species are functionally important to forest ecosystems. Wood-dependent organisms play critical roles during the processes of woody debris decomposition and nutrient cycling through multitrophic interactions (Edmonds and Eglitis 1989; Harmon et al. 1994); they influence forest structure and composition (Harmon et al. 1986; Kuuluvainen 2002). Their availability affects forest bird communities, notably by limiting the population size of numerous species of woodpeckers, important cavity providers for secondary cavitynesters (Martin and Eadie 1999; Bednarz et al. 2004). Some saproxylic organisms have narrow micro-habitat requirements and poor dispersal capacities (Siitonen 2001; Grove 2002). This makes them a group of species particularly susceptible to habitat loss and fragmentation and, as a result, extinction-prone. Accordingly, Speight (1989) estimated some $40 \%$ of Europe's saproxylic invertebrates to be already on the verge of extinction over much of their range while the majority of the remainder would be in decline. Due to their specificity for substrate and microclimatic conditions characterising mature timber habitat, saproxylic communities have been suggested as useful bio-indicators of forest quality, and as tools in the process of identifying important forests for nature conservation (Speight 1989; Good and Speight 1996).

As a general pattern, saproxylic insects respond to different aspects of dead wood availability, such as total amount (Økland et al. 1996; Martikainen et al. 2000), quality (Irmler et al. 1996; Schiegg 2001; Hövemeyer and Schauermann 2003; Similä et al. 2003) or spatial distribution (Schiegg 2000). Among them, longhorn beetles (Coleoptera, Cerambycidae) and hoverflies (Diptera, Syrphidae) share similar broad ecological requirements. They all rely upon diverse wooden micro-habitats for reproduction (Jeniš 2001; Speight et al. 2003a). At the tree level however, while the saproxylic beetles mainly select freshly dead woody habitats for oviposition, saproxylic hoverflies also colonise microhabitats of overmature and senescent trees (Bense 1995; Speight and Good 2003). Trunk cavities, rot-holes, insect workings, sap runs and woody surfaces under loose bark are key biotopes for saproxylic syrphids (Speight et al. 2003b). Among the 100 European saproxylic Syrphidae species with terrestrial larval activity, $66 \%$ have larvae only found on overmature/senescent trees, against $9 \%$ with larvae only living in woody debris (Speight et al. 2004). The remaining $25 \%$ of the species select microhabitats associated with both old trees and dead wood. On the other hand, most adult Syrphidae are obligate flower visitors, depending on both pollen and nectar of actinomorphic plants (e.g., Apiaceae, Asteraceae, Ranunculaceae, Rosaceae) to develop their reproductive organs and sustain their costly flight behaviour, respectively (Ellis and Ellis-Adam 1993; Branquart and Hemptinne 2000). By contrast, as many as $60 \%$ of the European saproxylic longhorn beetle species are reported as not visiting flowers (Jeniš 2001). Among potential benefits, flower resources affect fitness-related traits of individuals like fecundity, longevity and dispersal success (Stürken 1964; Haslett 1989; Hanks et al. 1998; Millar et al. 2003). Flowers are also used as mating sites by an array of longhorn beetle and hoverfly species (Villiers 1978; Vockeroth and Thompson 1981; Gilbert 1986; Barbalat 2002). Such difference in preferences for larval microhabitats and floral resources between the two species groups is expected to influence their response to habitat changes and, more specifically, to dead wood and overmature tree supplies.

In this paper, we aim to clarify environmental factors that explain species diversity and abundance of saproxylic longhorn beetles and hoverflies, including threatened ones, among mature beech Fagus sylvatica and oak Quercus spp.-dominated forest stands of southern Belgium. Among potential determinants we relate saproxylic diversity to local vegetation structure and composition, altitude and landscape composition. Particular attention is paid to the effects of dead wood and old tree availability, two limiting resources in modern forest landscapes, as well as to flower supply on community and species responses. Our study sites are located amongst those deciduous forest habitats with the largest amount of coarse woody debris that are still available in Belgium, with a total stand volume up to $150 \mathrm{~m}^{3} \mathrm{ha}^{-1}$. This paper contributes to current attempts to improve predictions of insect distributions by linking focal habitat resources with species biology (Dennis et al. 2003; Dennis 2004; Shreeve et al. 2004). 


\section{Material and methods}

\section{Study area and site selection}

The field study was conducted in the southern part of Belgium from 2002 to 2003. A total of 22 mature deciduous forest stands were selected, distributed over four natural regions (Figure 1). Dominant tree species (oak/beech) and the availability of woody debris were the main criteria of site selection. Sites were organised by pairs (11 pairs), with paired stands showing similar plant composition, soil properties and abiotic factors (elevation, rainfall, temperature) but with contrasting management histories. Accordingly, paired stands were thereafter classified as having a high $\left(>25 \mathrm{~m}^{3}\right.$ of dead wood per ha) or a low $\left(<25 \mathrm{~m}^{3}\right)$ amount of coarse woody debris. They were located $2-10 \mathrm{~km}$ apart from each other.

\section{Insect data}

We used various kinds of traps to sample the insect composition of the different study sites. In the 11 sites with a high amount of dead wood, insect traps were situated where woody debris was most abundant. In each stand, 8 flight-window traps (W) were placed and numbered along $2 \times 100 \mathrm{~m}$ perpendicular transects crossing each other in their middle, with the traps number $1,2,3,4$ in the north-south direction, and the traps 5, 6, 7, 8 in the west-east direction. Traps $1-2,3-4$ and 5-6, 7-8 were suspended on a metal wire between trees $25 \mathrm{~m}$ apart, leaving the transect junction (between

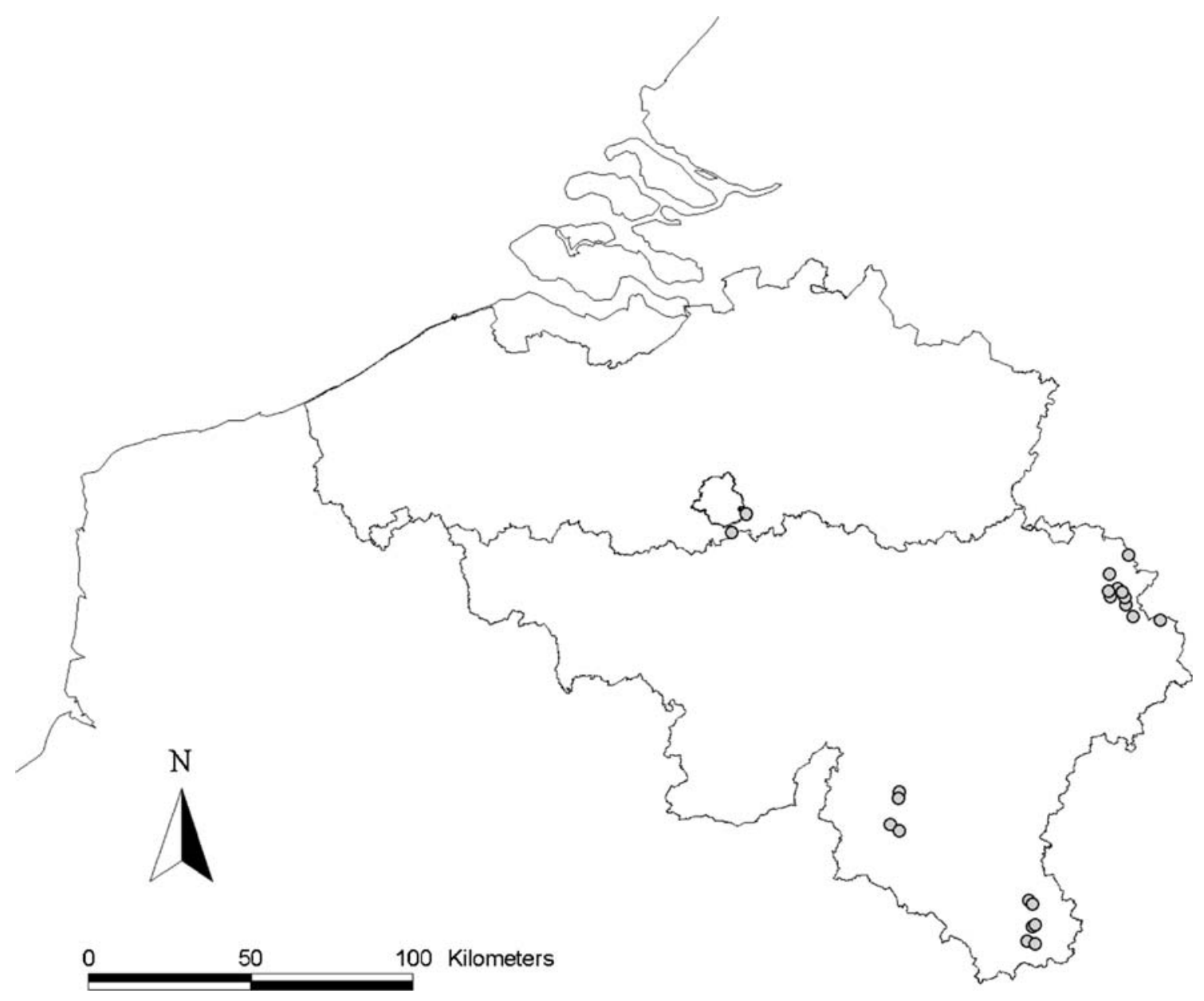

Figure 1. Location of the study sites (circles) 
traps 2-3 and 6-7) free of window traps. Flightwindow traps consisted of two perpendicular intercepting $40 \times 60 \mathrm{~cm}$ transparent plastic panels, with a funnel leading to a container below the panels filled with water, salt and detergent. Traps were covered with a transparent $80 \times 80 \mathrm{~cm}$ plastic roof to minimise funnel obstruction with plant debris and to divert rainfall. To optimise the capture of insects that have contrasting flight behaviour and host preferences, we also used 2 Malaise (M) and 3 stump-emergence (E) traps. Malaise tents (with a second one only in 2003) were located some $30 \mathrm{~m}$ apart near the centre of the plot in a sunny place, with ethylene-glycol in the container to preserve the insects. They were protected from wild boars Sus scrofa by a robust metal fence stretched on wooden posts. In 2003, together with the second Malaise trap, we placed 1 IPM Intercept Panel Trap (PS), made of black cardboard panels, where the sampling transects crossed. Sampling covered the period from March to October 20022003. Traps were emptied once a month, and regular visits were made in May-June to minimise the risks of trap funnel obstruction at times of maximum insect activity.

We extracted data on the propensity of adult longhorn beetles to visit flowers from Jeniš (2001) and Bense (1995). Following Speight et al. (2004) criteria on microhabitat preferences of European Syrphidae, we classified the collected hoverfly species as saproxylic when their larvae exclusively live on overmature/senescent trees, on dead trees, or both. We estimated the number and abundance of threatened longhorn and hoverfly species in our study plots according to national red lists from Germany (Schmidl and Bussler 2003; von der Dunk et al. 2003), assuming these checklists to provide conservative information on insect species status in Belgian forests.

\section{Site characteristics}

We were interested in relating insect data to factors assumed to have direct measurable effects on saproxylic assemblages (vegetation structure and composition, floral resources, dead wood supply and quality, altitude). Patch occupancy was also studied in relation to the surrounding landscape composition, and in particular to the extent of exotic conifer plantations. This variable, a good indicator of the level of habitat continuity and connectivity over time (conifer plantations were absent from Belgian forest landscapes in the 18th century; see Ferraris' historical maps), was assumed to have long-lasting effects on the saproxylic population processes at the landscape level and, therefore, population persistence in the deciduous forest remnants (Mazerolle and Villard 1999). Habitat description procedures followed pan-European recommendations for data collection in forest reserves (Hochbichler et al. 2000). Schematically, the sampling design was a collection of circular plots of different sizes and locations on a grid network of $50 \times 50 \mathrm{~m}$, according to the habitat features to be measured (Fayt et al. 2003).

In each stand, we used five nested sample plots of 0.05 ha and 0.1 ha, with one located at the crossing of the insect sampling transects and the others $50 \mathrm{~m}$ apart in the cardinal directions, centred on the perimeter flight-window traps $(1,4$, 5 , and 8 ). In the 0.05 ha plots, we measured the volume of fallen branches with a diameter between 5 and $9 \mathrm{~cm}$. We quantified the volume of standing living and dead trees with a girth at breast height between 16 and $125 \mathrm{~cm}$. We also estimated the volume of logs with a diameter at the smallest end between 10 and $40 \mathrm{~cm}$. Larger living trees, snags, logs and fallen branches as well as stump volume and the number of tree species were measured in the 0.1 ha plots. The volume of living and freshly dead trees was estimated from yield volume tables (Dagnelie et al. 1999), based on girth and height measurements. We applied the measurements guidelines developed by Harmon and Sexton (1996) to evaluate the volume of remaining woody debris. The volume of broken snags and stumps was calculated using a formula for a frustum of a cone: $V=H\left(A_{\mathrm{b}}+\left(A_{\mathrm{b}} A_{\mathrm{t}}\right)^{0.5}+A_{\mathrm{t}}\right) / 3$, where $H$ is the height, and $A_{\mathrm{b}}, A_{\mathrm{t}}$ are respectively the areas of the base and top. We used Newton's formula to evaluate $\log$ volume: $V=L\left(A_{\mathrm{b}}+4 A_{\mathrm{m}}+A_{\mathrm{t}}\right) / 6$, where $L$ is the length, and $A_{\mathrm{b}}, A_{\mathrm{m}}$, and $A_{\mathrm{t}}$ are respectively the areas of the base, middle and end of the trunk. Fallen branch volume was derived from Huber's formula: $V=\left(\pi \times d^{2} / 4\right) \times L$, where $d$ is the middle diameter and $L$ the length of the branch. Modified after Hunter (1990), four decay classes were used to describe the stage of wood decomposition of the different categories of woody debris. The first stage included snags, logs, 


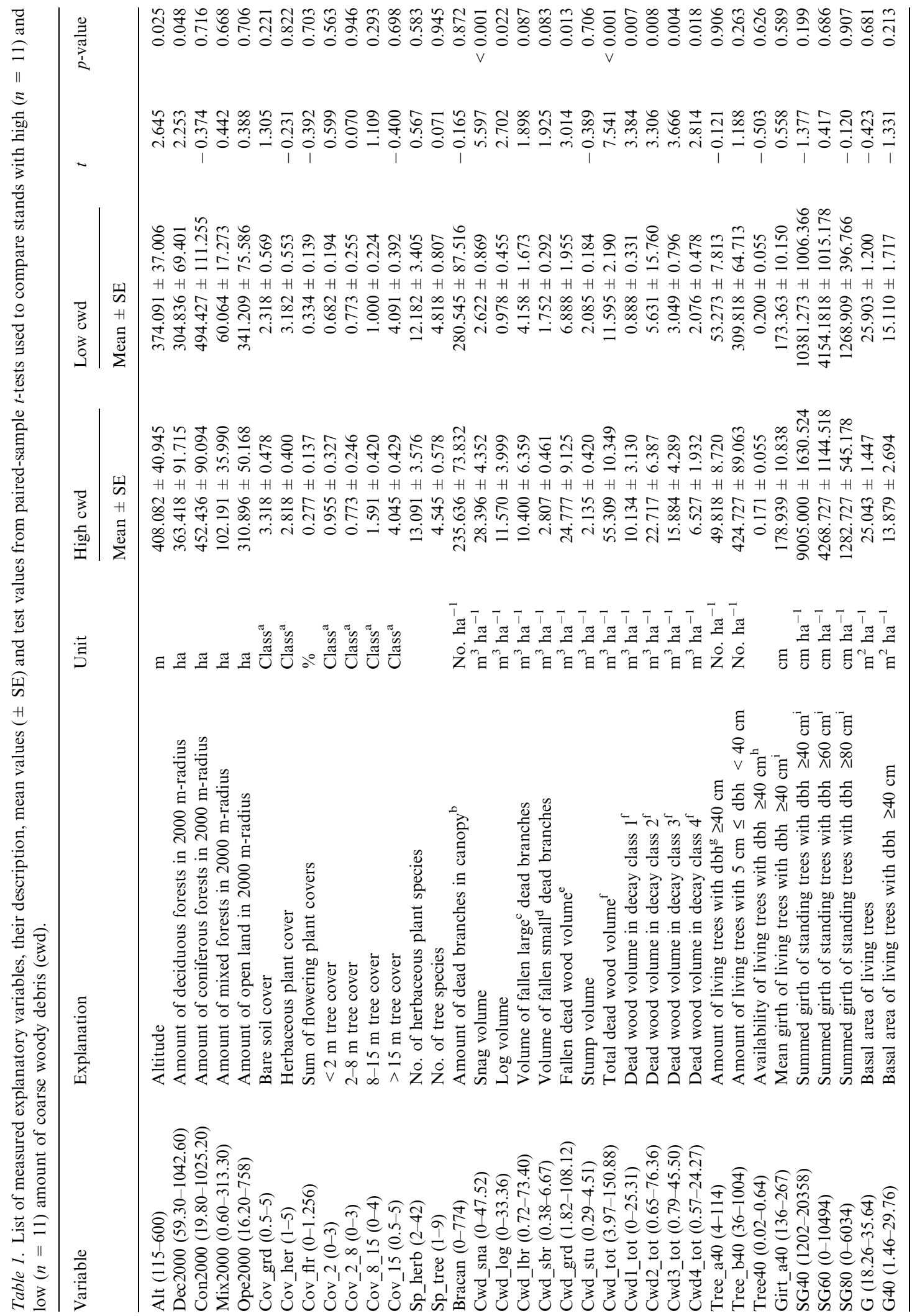


branches and stumps with hard wood and intact bark cover and the second the substrates with bark partly loose. Wooden microhabitats in the third and fourth classes lacked bark, but with a friable wood texture in the last stage, leading to visible changes in their original shape.

We conducted a plant inventory and evaluated the bare soil, herb and tree layer covers in a 0.05 ha plot delimited from the centre of the 0.8 ha plot containing the insect traps. An index of floral resources was built for each site by summing the respective cover of plants known to produce accessible amounts of pollen and nectar, among which were Crataegus laevigata (Poir.) DC., Crataegus monogyna Jacq., Frangula alnus Mill., Prunus avium L., Prunus spinosa L., Sorbus aucuparia L., Anemone nemorosa L., Angelica sylvestris L., Filipendula ulmaria (L.) Maxim., Hedera helix L., Hypericum pulchrum L., Potentilla reptans sp., Potentilla sterilis (L.) Garcke, Ranunculus ficaria L., Ranunculus repens L., Rubus idaeus L., Valeriana dioica L., Rosa sp., Rubus sp., and Taraxacum sp.

We finally looked at landscape composition by calculating from satellite imagery and field mapping the amount of deciduous/coniferous/mixed forests and open fields (clear-cut, pasture, peatland, meadow) in a 1256 ha plot (2000 m radius) from the insect transect junction.

Overall, 37 variables were included as potential explanatory factors in the analyses (Table 1). The different measurements were carried out from 2002 to 2004 .

\section{Statistical analyses}

All the analyses were carried out by use of SAS Enterprise (version 2.0), except for ordination techniques which were conducted with $\mathrm{CANOCO}$ 4.0 for Windows (ter Braak and Smilauer 1998). Default settings of the gradient analyses methods included species scores divided by standard deviation, species data transformation and centring. Counts were $\log _{10}(x+1)$ and percentages and proportions arcsin-square root transformed to normalize their distributions, if necessary.

We first conducted a validation test of our sampling scheme stratified by dead wood supply (high/ low) using discriminant analyses. This allowed us to identify the set of variables among the 37 
included in the analyses that best explained the criteria applied when selecting the study sites. The importance of dead wood variables in separating sites classified as either with either high or low amount of coarse woody debris was additionally tested by comparing the mean values of the different variables between pair stands using paired-sample $t$-tests, followed by a sequential Bonferroni correction $(\alpha=0.05)$ to control for the error rate from multiple comparisons of means (Rice 1989).

The sampling efficiency of insect communities in our study sites was assessed by drawing individual species accumulation curves in relation to the sampling effort applied over the study period (8 Window (2002) +8 Window (2003) and 1 Malaise (2002) + 2 Malaise (2003) traps). This procedure combines the average number of species per sampling unit, and variation in species composition among them, into the cumulative number of species. The shape of the curve is a good indicator of sampling efficiency, with the slope approaching the asymptote as the sample estimate becomes closer to the true community value. For each site, sampling efficiency was estimated by calculating the ratio $a / N$, where $a$ is the number of species that were sampled only once, and $N$ the number of sampling units (traps). This index expresses the slope of the curve when the whole community is inventoried, that is, the number of new species that, on average, would be expected to be gained if adding one more insect trap (Lauga and Joachim 1987). With a ratio $a / N=0.1$ for example, we would need 10 more traps to gain a new species.

The effect of dead wood supply on insect distribution was first tested by comparing species numbers and abundances between paired stands $(1,1)$, with high or low amount of dead wood $(1,2)$ and with year as a confounding factor $(1,2)$. Analysis of variance was performed according to a split plot design, with dead wood as a main plot factor and year as a subplot factor. Deadwood and year were considered as fixed effects, while pair and deadwood $\times$ pair effects were included as random factors in the model.

A principal component analysis (PCA) was then conducted to describe the general structure of the species pool, based on their abundance estimates in relation to each other and the environmental data (indirect gradient analysis). Besides clarifying relationships between variables, this linear technique is particularly useful for inferring the relative importance of environmental variables correlated with main trends of species and abundance estimates. The number of dimensions of the ordination space to be retained for the ordination analysis was defined so that the proportion of the explained variation reached cumulatively twothirds of the total variance of the data set. Both species numbers and abundances were represented on the biplot, given their similar contributions to the first two axes. We then performed partial Redundancy Analyses (pRDA), a direct gradient analysis, in order to calculate the proportion of variation of our biological data set (species richness and abundance) that is explained by a set of independent environmental variables once the effect of spatial structure (here, the region) was taken into account. Following this partially constrained procedure, information that could be explained by the regional effect was first extracted and then the explanatory variables were used to account for the residual variation. Only individual variables that explained a significant part $(\alpha=0.05)$ of the relationship were included in the model. They were identified by a manual forward selection procedure. We made two ordinations, with and without non-saproxylic Syrphid data. The significance of the models was tested by Monte Carlo permutation tests (999 permutations under full model).

Finally, since species are most likely to have a unimodal species response curve in relation to environmental gradients (i.e. species are non linearly related to each other, with bell-shaped curves along the gradients), we also performed a Canonical Correspondence Analysis (CCA) on species abundance profiles to detect possible species-environmental relationships (ter Braak 1988). As with the partial RDA, we decomposed species variance into non-spatial environmental, spatial environmental, spatial non-environmental and undetermined components by removing the effect of spatial structure (region). In order to force the ordination to test the working hypothesis (effects of dead wood, flower supply and old trees), we limited the analyses to a subset of explanatory factors expected to positively affect the distribution of saproxylic insects: vegetation cover ( $\mathrm{VG})$, the amount of dead wood (DW), and the availability of old trees (OT). The variables associated with vegetation cover were the availability of floral resources (Cov_flr) and tree species (Sp_tree), with dead wood the 
Table 2. Results of Stepwise Discriminant Analysis showing the sets of environmental variables best explaining the criteria used for site selection.

\begin{tabular}{|c|c|c|c|c|c|c|c|}
\hline Criteria & Value & Step no. & Variables entered & Partial $R^{2 \mathrm{a}}$ & Model $R^{2 \mathrm{~b}}$ & $F$-value & $p$-value \\
\hline \multirow[t]{3}{*}{ Dead wood } & High/Low & 1 & Cwd_tot & 0.722 & 0.722 & 51.83 & $<0.001$ \\
\hline & & 2 & Cwd_lbr & 0.366 & 0.823 & 10.94 & 0.004 \\
\hline & & 3 & Cov_2 & 0.114 & 0.844 & 2.32 & 0.145 \\
\hline
\end{tabular}

${ }^{\mathrm{a}}$ Proportion $(\%)$ of variance explained by the variables entered in the model.

${ }^{\mathrm{b}}$ Total proportion $(\%)$ of variance explained by the model.

Significant effects $(p<0.05)$ are in bold. See Table 1 for explanation of acronyms.

volume of standing (Cwd_sna) and fallen trees (Cwd_log), and with old trees the mean girth (Girt_a40) and summed girth (SG80) of large trees.

Following du Bus de Warnaffe and Dufrêne (2004), we decomposed the total variation of our insect species/sites files as:

$$
\begin{aligned}
\mathrm{A}= & \mathrm{A} \cap\left(\mathrm{B}_{1} \mid \mathrm{B}_{2} \cap \mathrm{B}_{3}\right)+\mathrm{A} \cap\left(\mathrm{B}_{2} \cap \mathrm{B}_{3} \mid \mathrm{B}_{1}\right)+\mathrm{A} \\
& \cap\left(\mathrm{B}_{2} \mid \mathrm{B}_{1} \cap \mathrm{B}_{3}\right)+\mathrm{A} \cap\left(\mathrm{B}_{1} \cap \mathrm{B}_{3} \mid \mathrm{B}_{2}\right)+\mathrm{A} \\
& \cap\left(\mathrm{B}_{3} \mid \mathrm{B}_{1} \cap \mathrm{B}_{2}\right)+\mathrm{A} \cap\left(\mathrm{B}_{1} \cap \mathrm{B}_{2} \mid \mathrm{B}_{3}\right)+\mathrm{A} \cap\left(\mathrm{B}_{1}\right. \\
& \left.\cap \mathrm{B}_{2} \cap \mathrm{B}_{3}\right)+\mathrm{A} \mid\left(\mathrm{B}_{1}+\mathrm{B}_{2}+\mathrm{B}_{3}\right)
\end{aligned}
$$

where $\mathrm{A}$ is the total variance of the species assemblages, $\mathrm{B}_{1}=\mathrm{VG}, \mathrm{B}_{2}=\mathrm{DW}, \mathrm{B}_{3}=\mathrm{OT}$, $\left(\mathrm{B} 1 \mid \mathrm{B} 2 \cap \mathrm{B}_{3}\right)$ is the variation explained by $\mathrm{VG}$ independently of the variation explained by the interaction between DW and OT (shared by both), $\left(B_{2} \cap B_{3} \mid B_{1}\right)$ the variation explained the interaction between DW and OT independently of VG and so on, $\left(B_{1} \cap B_{2} \cap B_{3}\right)$ the variation explained by the interaction between the three factors $\mathrm{VG}$, DW and $\mathrm{OT}$, and $\mathrm{A} \mid\left(\mathrm{B}_{1}+\mathrm{B}_{2}+\mathrm{B}_{3}\right)$ the variation not explained by $\mathrm{B}_{1}, \mathrm{~B}_{2}, \mathrm{~B}_{3}$ and their interactions. Thus, the amount of species variance (A) solely explained by one factor (here VG) was obtained from: $\mathrm{A} \cap(\mathrm{VG} \mid \mathrm{DW} \cap \mathrm{OT})+\mathrm{A} \cap(\mathrm{VG} \cap \mathrm{DW} \mid \mathrm{OT})+$ $\mathrm{A} \cap(\mathrm{VG} \cap \mathrm{OT} \mid \mathrm{DW})+\mathrm{A} \cap(\mathrm{VG} \cap \mathrm{DW} \cap \mathrm{OT}) . \quad$ The amount of unexplained variation was deduced from the above equation. Those different components were calculated by performing series of CCA with variation partitioning.

\section{Results}

\section{Sampling scheme}

On average, stands classified with either a high or a low amount of dead wood mostly differed in terms of their dead wood supply among the four decay classes, together with the altitude and the extent of native deciduous forests in the surrounding landscape (Table 1). After a Bonferroni correction, only the total amount of woody debris and snag volume were significant at the 0.05 level. Accordingly, discriminant analyses revealed that, among the different environmental variables, the total volume of coarse woody debris best separated the two stand categories $(p<0.001)$ (Table 2$)$.

\section{Sample sizes and sampling efficiency}

Catches yielded altogether 30 longhorn beetle (Cerambycidae) species (1637 individuals) and 106 hoverfly (Syrphidae) species (3020 individuals, Table 1 and Appendix 1). Among the longhorn beetles, 19 species were flower visitors. Overall, 27 species of Syrphidae were saproxylic, among which 20 were known to colonise both old and dead trees and seven had larvae exclusively associated with microhabitats of overmature trees. None of the species were dead wood specialists. According to German Red Lists of Cerambycidae and Syrphidae, we found six longhorn beetle and 11 hoverfly species listed as threatened (Appendix 1).

In most study sites, the number of longhorn beetle species collected with window traps (W) approached the true community value, as suggested by the different species accumulation curves tending towards the asymptote (Figure 2). Accordingly, 67\% (14/21) of the sites had an $a / N$ value well below 0.5 (i.e., sites that would require more than two additional traps to collect a new species). In only one site would the addition of one trap allow the capture of more than one new species $(a / N=1.50)$. Likewise, 3 Malaise traps (M) allowed an effective sampling of local cerambycid communities, since $40 \%(8 / 20)$ of the 


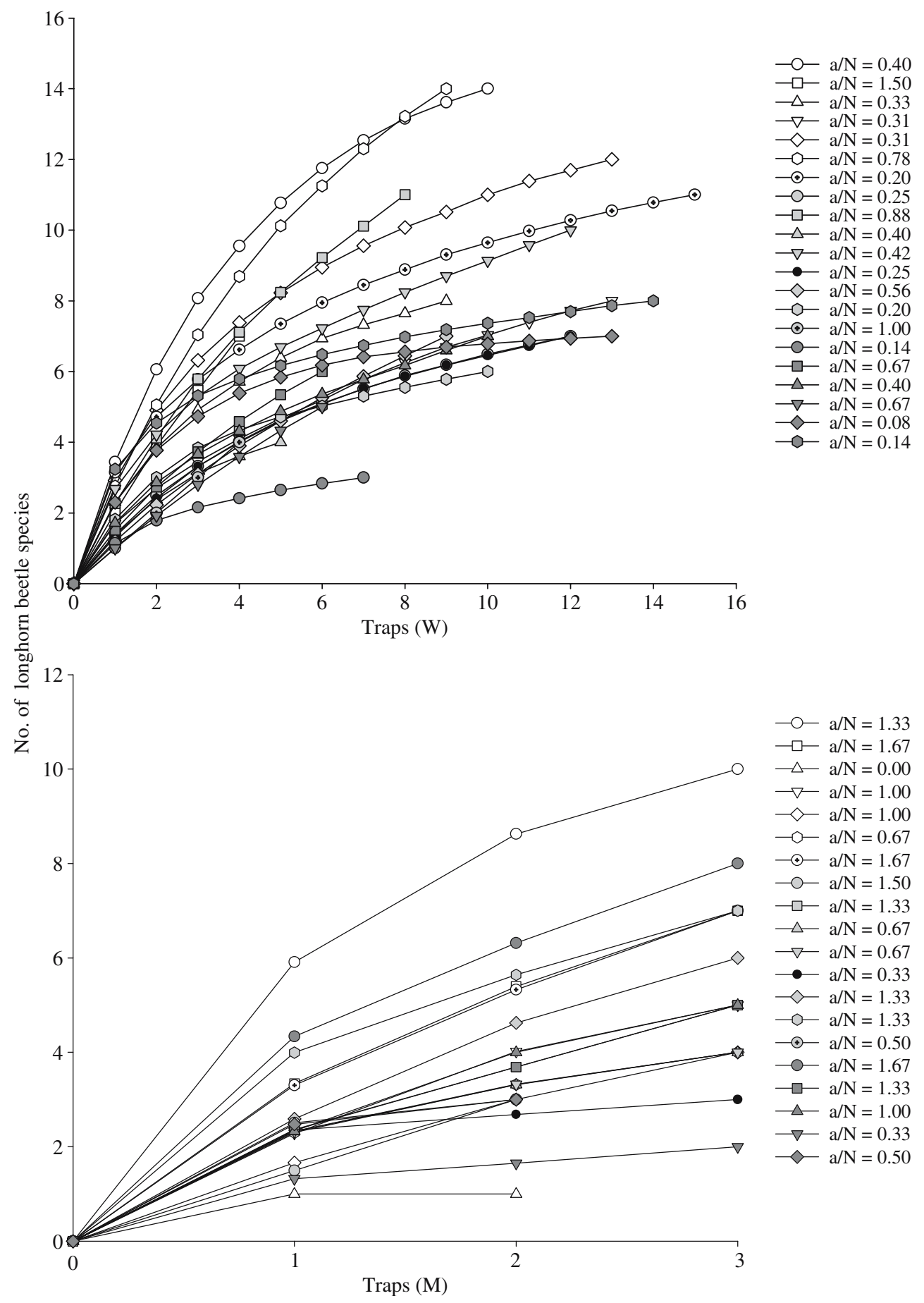

Figure 2. Cumulative number of longhorn beetle species as a function of the sampling effort (number of window (W) and Malaise (M) traps). Data are cumulated for 2002-2003. $a / N$ gives the number of new species that, on average, would be expected to be gained with an additional trap (see text). 


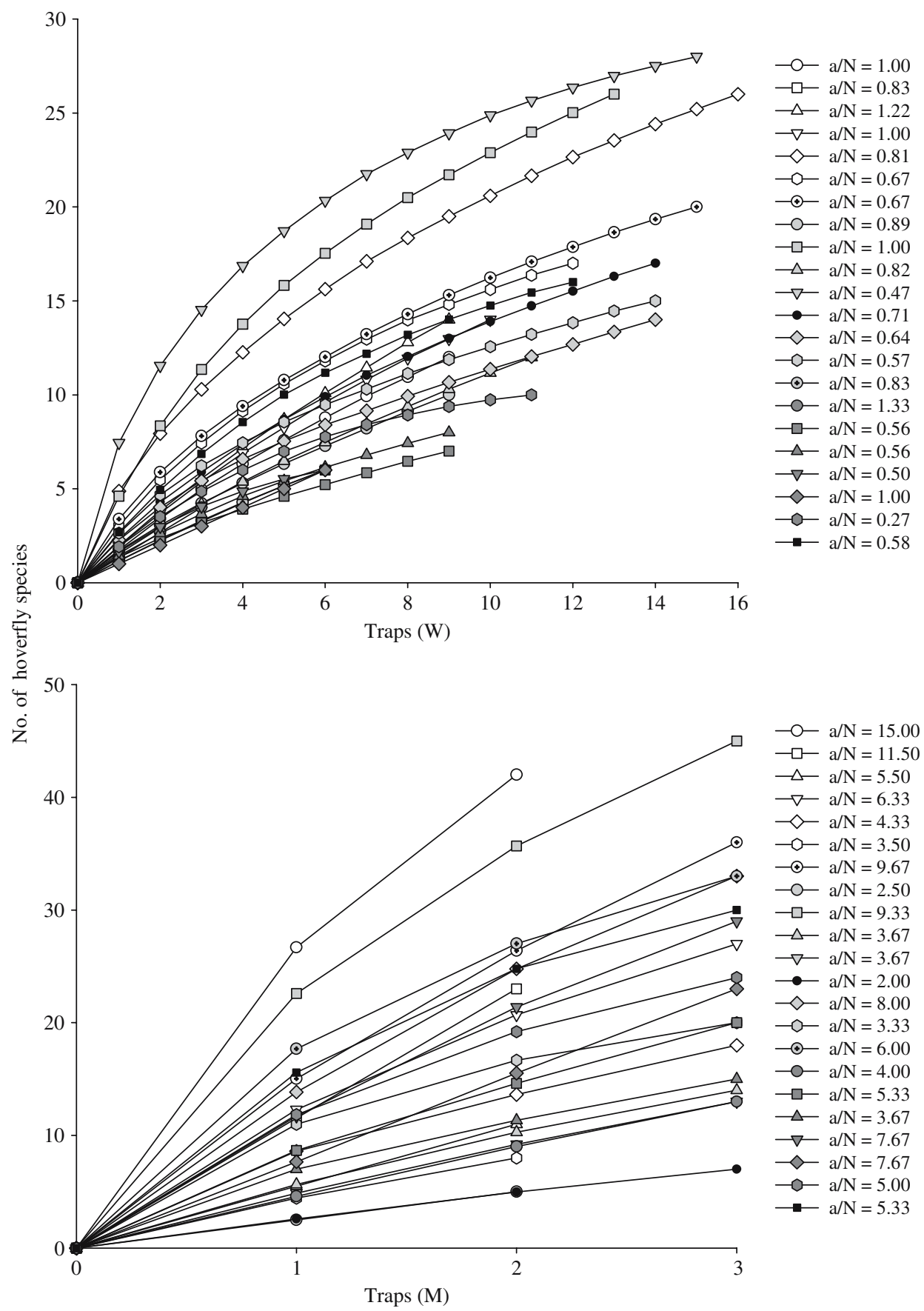

Figure 3. Cumulative number of hoverfly species in relation to trapping effort (Window and Malaise traps), with data cumulated for 2002-2003. $a / N$ is an indicator of sampling efficiency (see text).

sites would need more than one Malaise trap to collect an additional new species $(a / N<1)$, and less than two new species would be found if one trap was added to the remaining $60 \%$ of sites $(1 \leq a / N<2)$.
Species accumulation curves revealed that 16 out of the 22 sites $(73 \%)$ would require more than one additional window trap to collect a new hoverfly species $(a / N<1) \quad$ (Figure 3$)$. Using Malaise traps, between two and 15 new hoverfly 


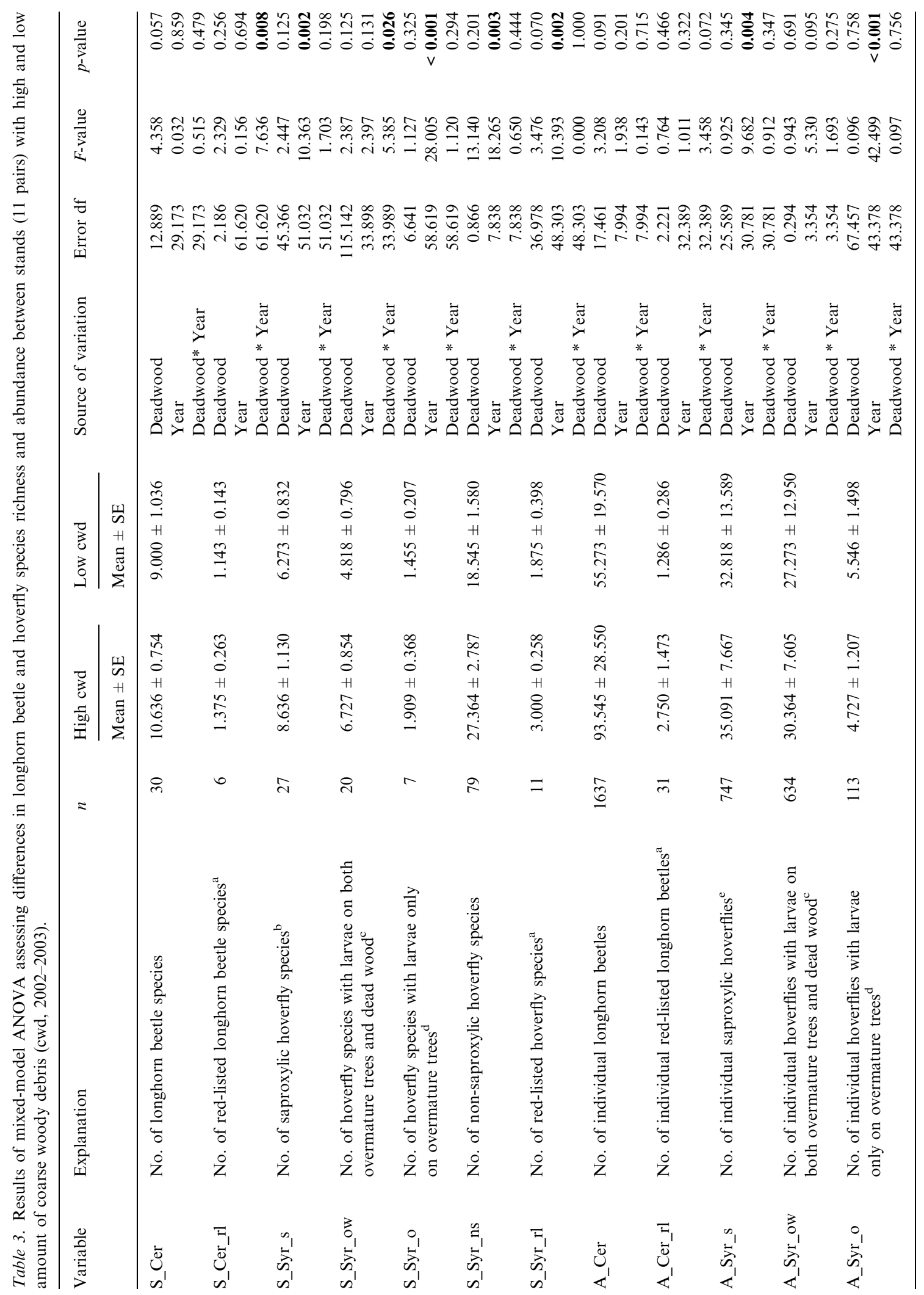


species were expected to be found following the addition of a fourth Malaise trap, although less than five new species would be found in nine $(41 \%)(a / N<5)$ of the 22 sites. When only considering saproxylic hoverflies, an additional Malaise trap would only produce three or less new species $(a / N \leq 3)$ in $75 \%$ of the sites.

\section{Insect numbers and dead wood}

The results of the mixed effect model (Table 3) indicated a positive (but not quite significant) impact of dead wood supply (high/low) on species diversity and abundance of longhorn beetles. Moreover, difference in dead wood explained variation in the number of Red List cerambycid species, depending on the year (a significant year $\mathrm{x}$ deadwood interaction). Looking at the hoverfly species data set, the number of saproxylic species with larvae living on both overmature trees and dead wood was positively affected by the amount of dead wood, although the relationship varied between years. The overall number of hoverfly species, whether saproxylic or not, and the richness in Red List species varied significantly between years, independently of the dead wood supply. A similar trend holds for individual numbers, although only the non-saproxylic hoverflies were significantly more abundant in stands with dead wood, in addition to yearly variation in numbers.

\section{Relationships between variables and variance partitioning}

The eigenvalues for the first two axes of the PCA ordination were 0.462 and 0.182 respectively, explaining cumulatively $46.2 \%$ and $64.4 \%$ of the variation in the total dataset. The first ordination axis contrasted stands embedded in deciduous forest landscapes, - with a high amount of dead wood, a well-developed and species-rich herb layer with abundant floral resources, - to stands surrounded by conifer plantations with a high basal area, bare soil and lacking woody debris (Figure $4 a$ ). The second axis polarised stands with large trees (beech-dominated) and a high volume of fallen large branches to multi-layered oakdominated stands with a high snag supply. 

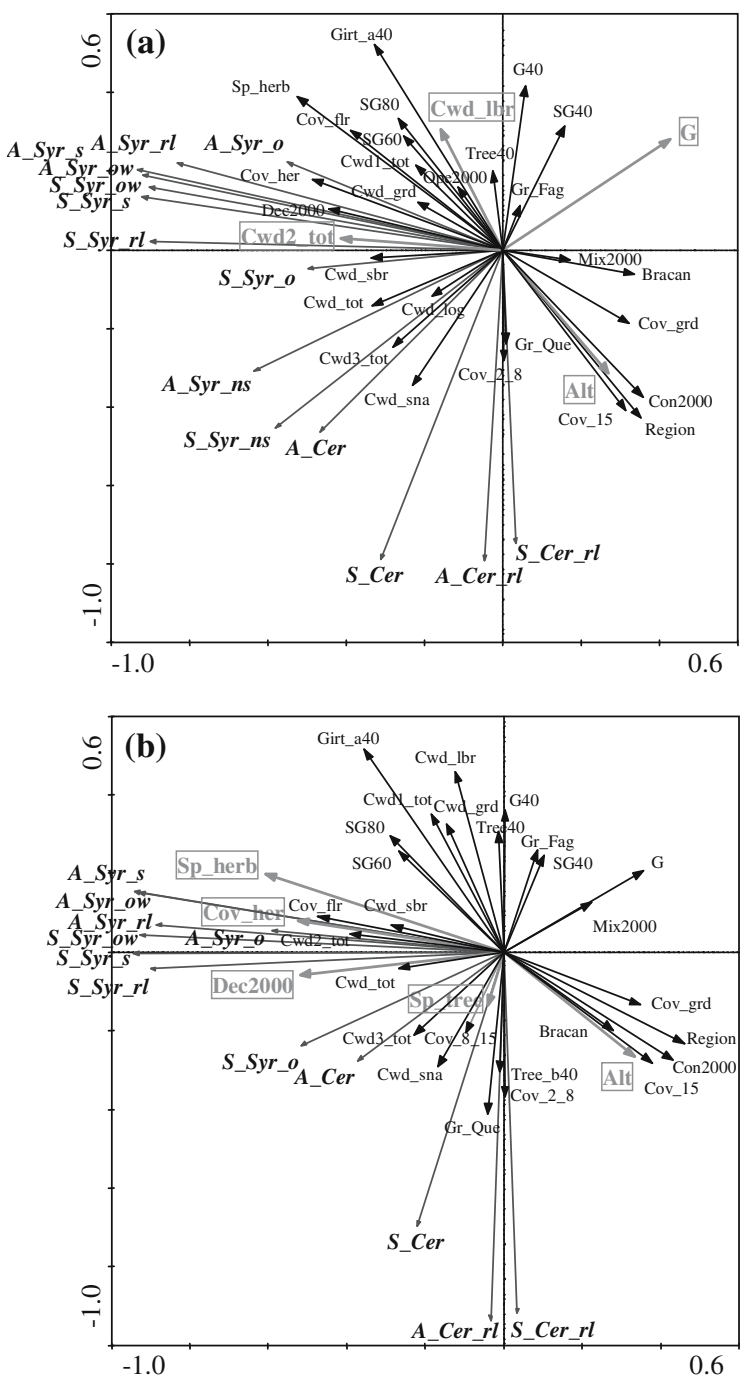

Figure 4. PCA-ordination of the biological and environmental descriptors plotted in the plane determined by the first two principal axes, with (a) and without (b) non-saproxylic hoverfly data. The dependent variables are shown in italic; the significant explanatory variables identified by pRDA (forward selection subroutine) after controlling spatial structuring of the data (Region) are framed. See Tables 1 and 3 for explanation of acronyms.

Once the non-saproxylic Syrphidae were removed from the data set, retaining only with saproxylic and threatened species assemblages, the first two ordination axes had eigenvalues of 0.491 and 0.200 respectively. They cumulatively explained $69.2 \%$ of the variance. Here, the axes contrasted stands with similar ecological conditions, but the second axis was more strongly correlated with oak and beech relative basal areas (Figure 4b).

PCA ordination indicated positive associations between cerambycid species diversity and snag volume. Among stands, those dominated by oak trees with a high snag volume were particularly favourable to cerambycid species diversity, including threatened species, while the extent of deciduous tree cover in the surrounding landscape had a clear positive impact on local abundances. By contrast, saproxylic and threatened syrphids were clearly avoiding closed shady stands with extensive bare soil cover, embedded in a coniferous landscape. Instead, they favoured stands with a well-developed and species rich herb layer providing pollen and nectar, together with the presence of large trees.

The partial RDA analyses revealed that the total explained variance of the biological data, including both species and individual numbers, was $47.2 \%$. Of this, $35.4 \%$ was explained by a linear combination of four non-spatial environmental variables, namely, in order of selection, the basal area, the total volume of dead wood with hard wood and bark partly loose, the volume of fallen large branches, and altitude (Figure 4a). Spatial structuring of the data not attributable to the environmental variables accounted for $9.4 \%$ of the total variance, indicating that no fundamental spatial structuring process has been missed. The remaining $2.4 \%$ was explained by the interaction between the biological data, the environment and spatial structuring (regional effect). Without the non-saproxylic Syrphidae data, a similar proportion of the biological data was explained (52.6\%). However, $40.4 \%$ of it was then explained by a different combination of ecological factors, including in order of selection, the numbers of herbaceous plant and tree species, the amount of deciduous forest in the surrounding landscape, the altitude, and the extent of herbaceous plant cover (Figure 4b). Spatial structuring of the data not attributable to the environmental variables accounted for $4.9 \%$ of the total variance; $7.3 \%$ was explained by the interaction between the biological data, the environment and spatial structuring. The species-environmental relationships described by the two models were non-random $(p<0.01)$.

Overall, the CCA indicated that $35.2 \%$ and $34.9 \%$ of the longhorn beetle and hoverfly species 
data were explained by the combined effects of the selected 'Vegetation', 'Dead Wood' and 'Old Tree' variables and their interactions, respectively (Figure 5). Vegetation variables (Cov_flr and Sp_tree) explained $\geq 30 \%$ of the variation for two longhorn beetle species (Gramnoptera ruficornis, Tetrops praeusta) and nine hoverfly species (Dasysyrphus hilaris, D. nigricornis, Eristalis nemorum, Ferdinandea cuprea, Merodon equestris, Temnostoma apiforme, $T$. bombylans, Xylota abiens, X. segnis). All the species were flower visitors (Appendix 1). The dead wood variables (Cwd_sna and Cwd_log) explained $\geq 30 \%$ of the variation for three longhorn beetle species (Anoplodera sexguttata, Pachytodes cerambyformis, Rhagium sycophanta) and four hoverfly species (Baccha elongata, Chrysogaster coemiteriorum, Cheilosia lenis, Pipiza bimaculata). None of those Syrphid species were dependent on dead woody substrates. The combination of old tree variables (Girt_a40 and SG80) explained $>30 \%$ of the
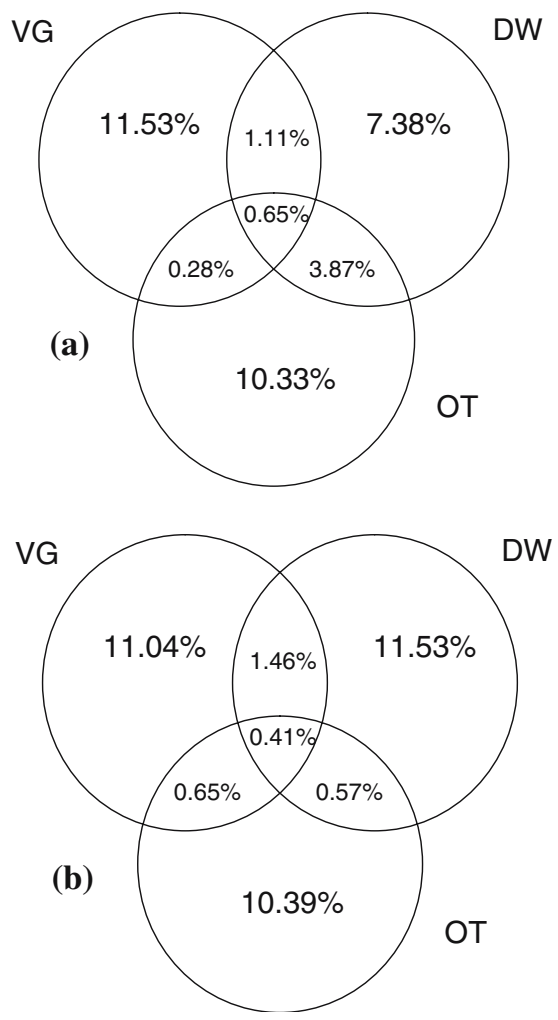

Figure 5. Part of variation of (a) longhorn beetle and (b) hoverfly species abundance explained by selected vegetation (VG), dead wood (DW) and old tree (OT) variables and their interactions. variation for four longhorn beetle species (Anoplodera sexguttata, Leptura aethiops, Pachytodes cerambyformis, Rhagium sycophanta) and four hoverfly species (Brachypalpus valgus, Paragus haemorrhous, Platycheirus peltatus, Pipizella viduata). Only B. valgus was associated with microhabitats of overmature trees (Appendix 1).

\section{Discussion}

Although both saproxylic longhorn beetles and hoverflies benefit from the presence of wooden substrates for reproduction, they differ in their requirements for floral resources and for microbiotopes of overmature and senescent trees. In this study, $63 \%$ of the longhorn beetle species collected were flower visitors, but they all depended on dead parts of branches, stems, stumps or roots to oviposit (Jeniš 2001). By contrast, most, if not all, the syrphids rely on both pollen and nectar to sustain foraging and egg production (Branquart and Hemptinne 2000), but none of those captured were specifically associated with dead wood microhabitats. Instead, $74 \%$ of the assemblage inventoried were species that occur on both woody debris and old trees and $26 \%$ species that only reproduce on overmature trees. This led us to expect contrasting responses between the two species groups in relation to dead wood and overmature tree availability in mature deciduous forest habitats differing in floral resources.

The study of general relationships between the insects and their environment revealed that $42 \%$ of the between-species variance was explained by a linear combination of five environmental variables. Stand openness and its effects on floral resources, tree dimensions and the volume of dead wood still retaining some bark cover were key determinants of local longhorn and hoverfly species diversity in the woodlands of southern Belgium. Once the non-saproxylic hoverfly species were removed from the analyses, however, the variance of the saproxylic and threatened insect data was explained by ecological variables that used to characterise European native temperate forests (Bengtsson et al. 2000): an abundant and species rich herb layer, numerous tree species, and a continuous deciduous forest cover over the landscape. Altitude also explained part of the variance, most probably because the majority of 
the deciduous stands with high dead wood supply are nowadays located on the least productive lands of Belgium (Table 1). But importantly, the two saproxylic species groups were clearly independent on the ordination axes, despite a lack of differences in their species abundance profiles in relation to vegetation, dead wood and old tree variables, presumably due to the presence of numerous rare species. This result demonstrates contrasting responses between the two groups for the measured environmental conditions.

The finding that paired stands, classified as a function of their dead wood supply (high/low), differed in their number of cerambycid species and, to a lesser extent, individuals (Table 3), with higher mean values in richer stands, indicates a positive impact of local tree mortality on longhorn beetle individual and population responses. The importance of dead wood supply per se in explaining such differences was supported by the results of the discriminant analyses. Among the 37 environmental variables that were included in the model, the pair stands were best separated by their total volume of woody debris. As shown on the PCA ordination biplot, oak-dominated stands with a high snag volume were particularly favourable to cerambycid diversity, including threatened species. In Belgium, of the 63 species of longhorn beetles associated with beech and oak forests, 32 are considered to live in both habitats and 27 to occur preferentially on oak trees (Muylaert 1990; Bense 1995).

Contrary to longhorn beetles, we found high numbers of saproxylic and threatened hoverfly species and individuals in stands with an open structure and large trees, providing ecological conditions for a well-developed and species rich herb layer, sources of pollen and nectar. They clearly avoided closed shady stands with extensive bare soil cover, embedded in a coniferous landscape. This is what would have been expected if, as predicted from a resource-based model of habitat exploitation, most of the saproxylic hoverfly species collected had larvae associated with overmature and dead tree microhabitats, in addition to obligate pollen and nectar requirements prior to oviposition. The importance of large trees for the development of microhabitats that benefit saproxylic syrphids is supported by Dufour (2003), who found the production of live tree microhabitats in our study plots to be a function of tree diameter, with the number of trunk cavities and rot holes increasing exponentially on trees with a diameter at breast height above $80 \mathrm{~cm}$. Surprisingly, the abundance of non-saproxylic species was higher in stands with dead wood. Most probably, those stands also contained unmeasured habitat resources and conditions that are important for the non-saproxylic community, such as abundant aphid populations or aquatic microhabitats (Dusek and Laska 1986; Speight et al. 2004).

In this study, despite geographically representative sampling among structurally complex habitats, we only captured $48 \%$ of the cerambycid species expected to be found in Belgian beech and oak forests, and $46 \%$ of the saproxylic Belgian hoverfly species. In Belgian forests, focal habitat resources such as dead wood and overmature trees have undergone general and dramatic reduction in their availability over the past centuries (Lemaire 2001; Branquart et al. 2005), reinforcing the longlasting effects of landscape transformation and fragmentation on local community composition. In our study stands, most of the dead wood available originated from storm events in the early 90s. Based on the latest forest inventories, Branquart et al. (2005) found the number of large trees (with diameter at breast height $>90 \mathrm{~cm}$ ) in our study region to be largely deficient compared to the situation in temperate natural forests. Oaks with large trunk diameter were especially scarce. Loss of the microhabitat continuity can be especially serious for saproxylic insect species with limited dispersal capabilities, such as those associated with the stable microhabitats of overmature trees (Nilsson and Baranowski 1997), or species that depend on temporary conditions of wood decay (Speight 1989). Speight (2002) showed that $80 \%$ or more of the Atlantic Region Fagus and Quercus forest-associated syrphid species occurring in Belgium are present, for all Fagus and Quercus microhabitat categories except overmature trees. Looking at the saproxylic species in particular, nearly half of them are categorised as being under threat (data from Verlinden and Decleer 1987). It is thus likely that the present-day communities we sampled were historically impoverished already at the start of the study, with just a few relict populations having survived in a handful of localities over the landscape. A consequence of this could be a progressive mismatch between dead 
wood and old tree variables and species distribution.

Alternatively, such low proportions may also partly be a normal result of low sampling effectiveness, especially when collecting rare and threatened species (Martikainen and Kouki 2003). Among syrphids for example, saproxylic species like Sphegina clunipes and S. elegans or Xylota segnis and $X$. sylvarum were mostly captured using stump emergence traps, suggesting limited movement propensity for some of the species. Among longhorn beetles, standardised direct searching in May-June 2004 produced three new species in one of the eight stands with the highest dead wood availability, among which one was a new species (Stenurella nigra) for the project. Low trap numbers may also result from high between-year variation in individual numbers, as noticed for hoverflies (Table 3). This may be owing to sampling effects associated with small population size (Owen 1981; Gilbert and Owen 1990). On the other hand, capture rate is a function of the movement patterns of individuals between their foraging, mating and oviposition habitat patches. The presence outside the study plots of focal habitats such as abundant flower resources at forest edges will influence the distribution patterns of insects (Warren and Key 1991; Barbalat 2002), and so their probability of being trapped. In order to optimise sampling efficiency however, we located our Malaise traps (the most effective sampling device we used for longhorn beetles and hoverflies - Appendix 1) in the few canopy openings of our sample plots. Also, results from species accumulation curves suggest that, overall, our sampling effort allowed a representative sampling of the studied communities. Importantly, most of the saproxylic insect species collected had a highly patchy distribution, with $43 \%$ of the longhorn beetle species and $44 \%$ of the saproxylic hoverfly species occurring in three out of the 22 stands inventoried, or $70 \%$ and $75 \%$ of the species among eight stands, respectively. Thus, our results support the idea that a large part of the species collected have residual and highly localised populations. We call for urgent restoration efforts over Belgian forest landscapes, starting from those very few forest patches that still possess a diverse fauna of saproxylics.

\section{Implications for insect conservation}

The results of this study allow us to propose standlevel management guidelines for the maintenance and restoration of saproxylic longhorn beetle and hoverfly fauna (Figure 6). They are based on the finding that, despite shared larval requirements for wooden substrates, the two saproxylic species groups respond differently to the availability of focal resources such as flowers, overmature trees and woody debris. We suggest however that both communities could benefit from the thinning and retention of large diameter trees, since it would promote the simultaneous production of both overmature and dead tree microhabitats and general light conditions necessary for floral development (Warren and Key 1991; Härdtle et al. 2003). The ecological changes would thus resemble those found in wind throw gaps, a transient vegetation stage of naturally dynamic forest habitats particularly attractive for saproxylic insects (Bouget and

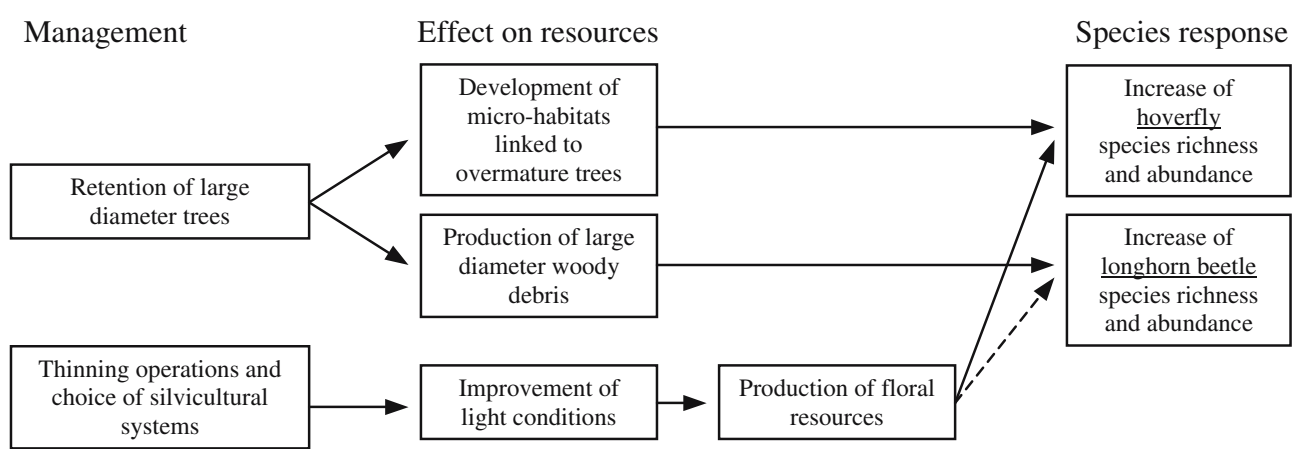

Figure 6. Proposed stand-level management methods to improve the habitat carrying capacity for both longhorn beetle and hoverfly species diversity. 
Duelli 2004), besides the development of new niches provided by the old living trees. Among silvicultural systems, we see shelterwood and group-felling as most appropriate in promoting such conditions, combining the presence of mature trees with the opening of the canopy that allows the development of a dense understorey and ground flora (Fuller and Peterken 1995). The maintenance and production of large-diameter living and dead trees is a function of harvesting standards: adopting extended rotations and green tree retention will favour production and restoration of key woody microhabitats for the saproxylic insects (Franklin et al. 1997; Grove 2002). Flower resources, a vital element for most of those insects, will greatly benefit from ecologically-sound management of forest gaps, margins and rides (Warren and Key 1991; Bouget and Duelli 2004). In line with Barbalat (2002), we consider oak trees to be highly favourable to saproxylic insect conservation, knowing their natural needs for stand openness and light. Moreover, maturing oaks naturally produce large dead branches in the lower part of their canopy, providing living conditions for the insects, even under traditional management regime. Recent distribution data from the Netherlands have shown how improvement of forest quality, in terms of forest cover, stand openness and amount of large and dead trees, can have a rapid and positive impact on numerous saproxylic hoverflies (Reemer 2005).

At the landscape scale however, we also suggest that the quality of the matrix should be taken into account in the process of identifying stands with a high potential for the saproxylic insect conservation. We found that the amount of deciduous forest in the surrounding landscape positively explained a significant part of the saproxylic and threatened species variance in the studied deciduous remnants. This suggests that landscape composition and connectivity are crucial for species distribution and local population persistence (Didham et al. 1996, 1998; Mazerolle and Villard 1999). In support of this finding, and despite the extensive ecological corridors they represent, Speight (2000) showed that recent conifer plantations only facilitate movement of generalist hoverfly species through the European landscape.

\section{Acknowledgments}

We are grateful to Jean-Yves Baugnée, Jonathan Lhoir and Marc Mignon for their contribution in insect searching, sorting and identification and plant surveys, as well as two anonymous reviewers for their critical comments. Martin C.D. Speight is acknowledged for giving advice on hoverfly sampling. We thank people working at the 'Division de la Nature et des Forêts' and 'AMINAL/Bos en groen' for providing information and access to our study sites. This study was financially supported by the Belgian Federal Science Policy Office.

Appendix 1. List of species, their abundance by trap type, larval foraging macrohabitat (overmature trees vs. coarse woody debris) adult propensity to visit flowers for foraging or mate searching ${ }^{\mathrm{b}}$ and status $^{\mathrm{c}}$.

\begin{tabular}{|c|c|c|c|c|c|c|c|c|c|c|}
\hline \multirow[t]{2}{*}{ Species } & \multicolumn{5}{|c|}{ Sample size } & \multicolumn{3}{|c|}{ Larval macrohabitat } & \multirow[t]{2}{*}{ Flower visitor } & \multirow[t]{2}{*}{ Red-listed } \\
\hline & $\mathrm{E}$ & M & PS & W & Total & omt-cwd & omt & cwd & & \\
\hline \multicolumn{11}{|l|}{ Cerambycidae } \\
\hline Alosterna tabacicolor & 0 & 13 & 0 & 20 & 33 & & & $x$ & $x$ & \\
\hline Anoplodera sexguttata & 0 & 4 & 0 & 6 & 10 & & & $x$ & $x$ & $x$ \\
\hline Brachyleptura maculicornis & 0 & 2 & 0 & 28 & 30 & & & $x$ & $x$ & \\
\hline Clytus arietis & 0 & 18 & 0 & 9 & 27 & & & $x$ & $x$ & \\
\hline Cortodera humeralis & 1 & 0 & 1 & 0 & 2 & & & $x$ & $x$ & $x$ \\
\hline Corymbia rubra & 0 & 1 & 0 & 33 & 34 & & & $x$ & $x$ & \\
\hline Eupogonocherus hispidulus & 1 & 6 & 0 & 5 & 12 & & & $x$ & & \\
\hline Gramnoptera ruficornis & 0 & 8 & 0 & 2 & 10 & & & $x$ & $x$ & \\
\hline Leiopus nebulosus & 0 & 3 & 0 & 8 & 11 & & & $x$ & & \\
\hline Leptura aethiops & 0 & 3 & 0 & 17 & 20 & & & $\times$ & $x$ & \\
\hline Leptura aurulenta & 0 & 2 & 0 & 0 & 2 & & & $x$ & $x$ & $x$ \\
\hline Leptura maculata & 0 & 20 & 0 & 208 & 228 & & & $x$ & $x$ & \\
\hline
\end{tabular}


Appendix 1. (Continued).

\begin{tabular}{|c|c|c|c|c|c|c|c|c|c|c|}
\hline \multirow[t]{2}{*}{ Species } & \multicolumn{5}{|c|}{ Sample size } & \multicolumn{3}{|c|}{ Larval macrohabitat } & \multirow[t]{2}{*}{ Flower visitor } & \multirow[t]{2}{*}{ Red-listed } \\
\hline & $\mathrm{E}$ & $\mathrm{M}$ & PS & $\mathrm{W}$ & Total & omt-cwd & omt & cwd & & \\
\hline Leptura quadrifasciata & 0 & 3 & 0 & 22 & 25 & & & $\times$ & $\times$ & \\
\hline Obrium brunneum & 0 & 0 & 1 & 0 & 1 & & & $\times$ & $\times$ & \\
\hline Obrium cantharinum & 0 & 0 & 0 & 1 & 1 & & & $x$ & & $x$ \\
\hline Oxymirus cursor & 1 & 7 & 1 & 18 & 27 & & & $x$ & & \\
\hline Pachytodes cerambyformis & 0 & 10 & 0 & 40 & 50 & & & $\times$ & $\times$ & \\
\hline Phymatodes testaceus & 0 & 0 & 0 & 1 & 1 & & & $x$ & & \\
\hline Plagionotus arcuatus & 0 & 0 & 0 & 2 & 2 & & & $\times$ & & \\
\hline Prionus coriarius & 1 & 0 & 0 & 7 & 8 & & & $\times$ & & \\
\hline Pyrrhidium sanguineum & 0 & 0 & 1 & 16 & 17 & & & $\times$ & & \\
\hline Rhagium bifasciatum & 6 & 103 & 1 & 47 & 157 & & & $x$ & $\times$ & \\
\hline Rhagium mordax & 22 & 187 & 1 & 117 & 327 & & & $x$ & $x$ & \\
\hline Rhagium sycophanta & 0 & 1 & 0 & 0 & 1 & & & $\times$ & $\times$ & $\times$ \\
\hline Saperda scalaris & 0 & 1 & 0 & 3 & 4 & & & $x$ & & \\
\hline Stenostola ferrea & 0 & 3 & 0 & 12 & 15 & & & $x$ & & $x$ \\
\hline Stenurella melanura & 1 & 27 & 0 & 544 & 572 & & & $\times$ & $\times$ & \\
\hline Stictoleptura scutellata & 0 & 0 & 0 & 5 & 5 & & & $\times$ & $\times$ & \\
\hline Tetropium castaneum & 0 & 0 & 0 & 4 & 4 & & & $\times$ & & \\
\hline Tetrops praeusta & 0 & 0 & 0 & 1 & 1 & & & $x$ & $x$ & \\
\hline \multicolumn{11}{|l|}{ Syrphidae } \\
\hline Baccha elongata & 0 & 18 & 0 & 3 & 21 & & & & $x$ & \\
\hline Blera fallax & 0 & 7 & 0 & 0 & 7 & $\times$ & & & $x$ & \\
\hline Brachypalpus laphriformis & 0 & 20 & 0 & 0 & 20 & & $\times$ & & $\times$ & \\
\hline Brachypalpoides lentus & 1 & 0 & 0 & 1 & 2 & $\times$ & & & $\times$ & \\
\hline Brachypalpus valgus & 0 & 2 & 0 & 0 & 2 & & $\times$ & & $\times$ & \\
\hline Brachyopa vittata & 0 & 0 & 0 & 2 & 2 & $\times$ & & & $x$ & \\
\hline Caliprobola speciosa & 34 & 41 & 0 & 1 & 76 & $\times$ & & & $\times$ & $x$ \\
\hline Chalcosyrphus nemorum & 0 & 17 & 0 & 1 & 18 & $\times$ & & & $\times$ & \\
\hline Chalcosyrphus piger & 0 & 1 & 0 & 0 & 1 & $\times$ & & & $x$ & \\
\hline Cheilosia lenis & 0 & 1 & 0 & 0 & 1 & & & & $\times$ & \\
\hline Cheilosia pagana & 0 & 2 & 0 & 3 & 5 & & & & $\times$ & \\
\hline Cheilosia scutellata & 0 & 2 & 0 & 0 & 2 & & & & $\times$ & \\
\hline Cheilosia variabilis & 0 & 1 & 0 & 0 & 1 & & & & $x$ & \\
\hline Chrysotoxum arcuatum & 0 & 53 & 0 & 1 & 54 & & & & $x$ & \\
\hline Chrysotoxum bicinctum & 0 & 81 & 0 & 0 & 81 & & & & $\times$ & \\
\hline Chrysogaster coemiteriorum & 0 & 1 & 0 & 4 & 5 & & & & $\times$ & $x$ \\
\hline Chrysogaster rondanii & 0 & 0 & 0 & 7 & 7 & & & & $x$ & \\
\hline Criorhina asilica & 0 & 3 & 0 & 0 & 3 & $\times$ & & & $\times$ & \\
\hline Criorhina berberina & 7 & 24 & 0 & 1 & 32 & $\times$ & & & $\times$ & \\
\hline Criorhina floccosa & 5 & 22 & 1 & 0 & 28 & $\times$ & & & $\times$ & $x$ \\
\hline Criorhina pachymera & 0 & 1 & 0 & 0 & 1 & $\times$ & & & $x$ & $x$ \\
\hline Dasysyrphus albostriatus & 0 & 2 & 0 & 0 & 2 & & & & $\times$ & \\
\hline Dasysyrphus hilaris & 0 & 6 & 0 & 2 & 8 & & & & $\times$ & \\
\hline Dasysyrphus lunulatus & 0 & 2 & 0 & 4 & 6 & & & & $x$ & \\
\hline Dasysyrphus nigricornis & 0 & 5 & 0 & 28 & 33 & & & & $\times$ & \\
\hline Dasysyrphus venustus & 0 & 56 & 2 & 110 & 168 & & & & $\times$ & \\
\hline Didea fasciata & 0 & 1 & 0 & 0 & 1 & & & & $\times$ & \\
\hline Didea intermedia & 0 & 1 & 0 & 0 & 1 & & & & $\times$ & \\
\hline Episyrphus auricollis & 0 & 5 & 0 & 0 & 5 & & & & $\times$ & \\
\hline Episyrphus balteatus & 0 & 268 & 0 & 115 & 383 & & & & $\times$ & \\
\hline Episyrphus cinctellus & 1 & 98 & 0 & 13 & 112 & & & & $\times$ & \\
\hline Epistrophe diaphana & 0 & 2 & 0 & 0 & 2 & & & & $x$ & \\
\hline Epistrophe eligans & 0 & 10 & 0 & 1 & 11 & & & & $\times$ & \\
\hline Epistrophe euchroma & 0 & 2 & 0 & 1 & 3 & & & & $\times$ & \\
\hline Epistrophe grossulariae & 0 & 3 & 0 & 0 & 3 & & & & $x$ & \\
\hline Epistrophe nitidicollis & 0 & 7 & 0 & 2 & 9 & & & & $x$ & \\
\hline
\end{tabular}


Appendix 1. (Continued).

\begin{tabular}{|c|c|c|c|c|c|c|c|c|c|c|}
\hline \multirow[t]{2}{*}{ Species } & \multicolumn{5}{|c|}{ Sample size } & \multicolumn{3}{|c|}{ Larval macrohabitat } & \multirow[t]{2}{*}{ Flower visitor } & \multirow[t]{2}{*}{ Red-listed } \\
\hline & $\mathrm{E}$ & M & PS & $\mathrm{W}$ & Total & omt-cwd & omt & cwd & & \\
\hline Eristalis lineata & 0 & 2 & 0 & 21 & 23 & & & & $\times$ & \\
\hline Eristalis nemorum & 0 & 0 & 0 & 4 & 4 & & & & $x$ & \\
\hline Eristalis pertinax & 0 & 29 & 1 & 175 & 205 & & & & $x$ & \\
\hline Eristalis piceus & 0 & 0 & 0 & 16 & 16 & & & & $x$ & \\
\hline Eristalis rupium & 0 & 1 & 0 & 0 & 1 & & & & $x$ & \\
\hline Eristalis tenax & 0 & 2 & 0 & 142 & 144 & & & & $x$ & \\
\hline Eupeodes corollae & 0 & 29 & 1 & 20 & 50 & & & & $x$ & \\
\hline Eupeodes lapponicus & 0 & 7 & 0 & 5 & 12 & & & & $x$ & \\
\hline Eupeodes latifasciatus & 0 & 6 & 0 & 2 & 8 & & & & $x$ & \\
\hline Eupeodes luniger & 0 & 3 & 0 & 1 & 4 & & & & $x$ & \\
\hline Ferdinandea cuprea & 0 & 24 & 0 & 0 & 24 & $x$ & & & $x$ & \\
\hline Ferdinandea ruficornis & 0 & 2 & 0 & 0 & 2 & & $\times$ & & $x$ & \\
\hline Helophilus pendulus & 0 & 47 & 0 & 13 & 60 & & & & $x$ & \\
\hline Helophilus trivittatus & 0 & 0 & 0 & 14 & 14 & & & & $x$ & \\
\hline Leucozona lucorum & 0 & 1 & 0 & 0 & 1 & & & & $x$ & \\
\hline Melangyna cincta & 1 & 42 & 2 & 9 & 54 & & & & $x$ & \\
\hline Melangyna lasiophthalma & 0 & 7 & 0 & 15 & 22 & & & & $x$ & \\
\hline Melanostoma mellinum & 0 & 47 & 0 & 16 & 63 & & & & $x$ & \\
\hline Melanostoma scalare & 0 & 132 & 1 & 70 & 203 & & & & $\times$ & \\
\hline Merodon equestris & 0 & 1 & 0 & 0 & 1 & & & & $x$ & $x$ \\
\hline Myathropa florea & 8 & 53 & 1 & 7 & 69 & & $\times$ & & $x$ & \\
\hline Neoascia podagrica & 0 & 0 & 0 & 1 & 1 & & & & $x$ & \\
\hline Orthonevra geniculata & 0 & 0 & 0 & 2 & 2 & & & & $x$ & $x$ \\
\hline Orthonevra intermedia & 0 & 2 & 0 & 0 & 2 & & & & $x$ & \\
\hline Paragus haemorrhous & 0 & 2 & 0 & 0 & 2 & & & & $x$ & \\
\hline Parasyrphus lineolus & 0 & 6 & 0 & 1 & 7 & & & & $x$ & \\
\hline Parasyrphus macularis & 0 & 1 & 0 & 1 & 2 & & & & $x$ & \\
\hline Parasyrphus malinellus & 0 & 13 & 0 & 1 & 14 & & & & $x$ & \\
\hline Parasyrphus punctulatus & 0 & 10 & 0 & 7 & 17 & & & & $x$ & \\
\hline Pipiza bimaculata & 0 & 1 & 0 & 0 & 1 & & & & $x$ & \\
\hline Pipiza fenestrata & 0 & 3 & 0 & 0 & 3 & & & & $\times$ & \\
\hline Pipiza lugubris & 0 & 1 & 0 & 0 & 1 & & & & $x$ & \\
\hline Pipiza luteitarsis & 0 & 1 & 0 & 0 & 1 & & & & $x$ & \\
\hline Pipiza quadrimaculata & 0 & 5 & 0 & 0 & 5 & & & & $x$ & \\
\hline Pipizella viduata & 0 & 2 & 0 & 0 & 2 & & & & $x$ & \\
\hline Pipizella virens & 0 & 2 & 0 & 0 & 2 & & & & $x$ & \\
\hline Platycheirus albimanus & 0 & 60 & 0 & 21 & 81 & & & & $x$ & \\
\hline Platycheirus angustatus & 0 & 8 & 0 & 0 & 8 & & & & $\times$ & \\
\hline Platycheirus clypeatus & 0 & 12 & 0 & 1 & 13 & & & & $x$ & \\
\hline Platycheirus parmatus & 0 & 1 & 0 & 0 & 1 & & & & $x$ & \\
\hline Platycheirus peltatus & 0 & 3 & 0 & 0 & 3 & & & & $x$ & \\
\hline Platycheirus scutatus & 0 & 1 & 0 & 1 & 2 & & & & $x$ & \\
\hline Platycheirus tarsalis & 0 & 1 & 0 & 1 & 2 & & & & $x$ & $x$ \\
\hline Pyrophaena rosarum & 0 & 1 & 0 & 0 & 1 & & & & $x$ & \\
\hline Rhingia campestris & 0 & 9 & 0 & 4 & 13 & & & & $x$ & \\
\hline Scaeva pyrastri & 0 & 0 & 0 & 2 & 2 & & & & $x$ & \\
\hline Scaeva selenitica & 0 & 3 & 0 & 0 & 3 & & & & $x$ & \\
\hline Sericomyia lappona & 0 & 11 & 0 & 17 & 28 & & & & $x$ & \\
\hline Sericomyia silentis & 0 & 69 & 0 & 42 & 111 & & & & $x$ & \\
\hline Sphegina clavata & 0 & 0 & 0 & 3 & 3 & & $\times$ & & $x$ & \\
\hline Sphegina clunipes & 17 & 0 & 0 & 3 & 20 & $x$ & & & $x$ & \\
\hline Sphegina elegans & 15 & 0 & 0 & 1 & 16 & & $\times$ & & $x$ & \\
\hline Sphaerophoria fatarum & 0 & 0 & 0 & 1 & 1 & & & & $x$ & \\
\hline Sphaerophoria scripta & 0 & 20 & 0 & 10 & 30 & & & & $x$ & \\
\hline Syrphus ribesii & 1 & 24 & 0 & 7 & 32 & & & & $x$ & \\
\hline
\end{tabular}


Appendix 1. (Continued).

\begin{tabular}{|c|c|c|c|c|c|c|c|c|c|c|}
\hline \multirow[t]{2}{*}{ Species } & \multicolumn{5}{|c|}{ Sample size } & \multicolumn{3}{|c|}{ Larval macrohabitat } & \multirow[t]{2}{*}{ Flower visitor } & \multirow[t]{2}{*}{ Red-listed } \\
\hline & $\mathrm{E}$ & $\mathrm{M}$ & PS & $\mathrm{W}$ & Total & omt-cwd & omt & cwd & & \\
\hline Syrphus vitripennis & 0 & 16 & 0 & 4 & 20 & & & & $\times$ & \\
\hline Temnostoma apiforme & 1 & 3 & 0 & 0 & 4 & $\times$ & & & $\times$ & $\times$ \\
\hline Temnostoma bombylans & 0 & 23 & 0 & 0 & 23 & $\times$ & & & $\times$ & \\
\hline Temnostoma vespiforme & 0 & 13 & 0 & 2 & 15 & $\times$ & & & $\times$ & \\
\hline Trichopsomyia flavitarsis & 0 & 1 & 0 & 0 & 1 & & & & $\times$ & \\
\hline Volucella bombylans & 0 & 3 & 0 & 4 & 7 & & & & $\times$ & \\
\hline Volucella inflata & 0 & 1 & 0 & 0 & 1 & & $\times$ & & $\times$ & $\times$ \\
\hline Volucella pellucens & 0 & 3 & 0 & 27 & 30 & & & & $\times$ & \\
\hline Xanthandrus comtus & 0 & 4 & 0 & 0 & 4 & & & & $\times$ & \\
\hline Xanthogramma laetum & 0 & 8 & 0 & 1 & 9 & & & & $\times$ & \\
\hline Xylota abiens & 0 & 8 & 0 & 0 & 8 & $\times$ & & & $\times$ & $\times$ \\
\hline Xylota jakutorum & 0 & 5 & 0 & 4 & 9 & $\times$ & & & $\times$ & \\
\hline Xylota meigeniana & 1 & 5 & 0 & 2 & 8 & $\times$ & & & $\times$ & $\times$ \\
\hline Xylota segnis & 97 & 48 & 0 & 82 & 227 & $\times$ & & & $\times$ & \\
\hline Xylota sylvarum & 96 & 29 & 0 & 1 & 126 & $\times$ & & & $\times$ & \\
\hline
\end{tabular}

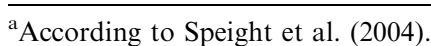

${ }^{\mathrm{b}}$ According to Jeniš (2001).

${ }^{\mathrm{c}}$ From German Red-Lists.

See text for trap details. $\mathrm{E}=$ Emergence trap, $\mathrm{M}=$ Malaise trap, $\mathrm{PS}=$ flight window trap, $\mathrm{W}=$ window trap; omt-cwd $=$ overmature trees and coarse woody debris, omt $=$ overmature trees, cwd $=$ coarse woody debris.

\section{References}

Barbalat S. 2002. Influence des pratiques sylvicoles sur quelques familles de Coléoptères dans le Jura suisse. Proceedings of the international workshop 'Forest management and conservation of saproxylic invertebrates', Mont Rigi (Belgium), March 11-12th 2002.

Bednarz J.C., Ripper D. and Radley P.M. 2004. Emerging concepts and research directions in the study of cavity-nesting birds: keystone ecological processes. Condor 106: 1-4.

Bengtsson J., Nilsson S.G., Franc A. and Menozzi P. 2000. Biodiversity, disturbances, ecosystem function and management of European forests. For. Ecol. Manage. 132: 39-50.

Bense U. 1995. Longhorn Beetles. Illustrated key to the Cerambycidae and Vesperidae of Europe. Margraf Verlag, Germany, $512 \mathrm{pp}$

Bouget Ch. and Duelli P. 2004. The effects of windthrow on forest insect communities: a literature review. Biol. Cons. 118: 281-299.

Branquart E. and Hemptinne J.-L. 2000. Selectivity in the exploitation of floral resources by hoverflies (Diptera: Syrphinae). Ecography 23: 732-742.

Branquart E., Vandekerkhove K., Bourland N. and Lecomte H. 2005. Les arbres sur-âgés et le bois mort dans les forêts de Flandre, de Wallonie et du Grand-Duché de Luxembourg. In: Proceedings of the International Symposium 'Bois mort et à cavités - une clé pour des forêts vivantes', Chambéry (France), October 25-28th 2004. In press

Dagnelie P., Palm R., Rondeux J. and Thill A. 1999. Tables de Cubage des Arbres et des Peuplements Forestiers. Les Presses Agronomiques de Gembloux, Gembloux, 128 pp.
Dennis R.L.H., Shreeve T.G and Van Dyck H. 2003. Towards a functional resource-based concept for habitat: a butterfly biology viewpoint. Oikos 102: 417-426.

Dennis R.L.H. 2004. Butterfly habitats, broad-scale biotope affiliations, and structural exploitation of vegetation at finer scales: the matrix revisited. Ecol. Entomol. 29: 744-752.

Didham R.K., Ghazoul J., Stork N.E. and Davis A.J. 1996. Insects in fragmented forests: a functional approach. Trends Ecol. Evol. 11: 255-260.

Didham R.K., Hammond P.M., Lawton J.H., Eggleton P. and Stork P.N. 1998. Beetle species responses to tropical forest fragmentation. Ecol. Monogr. 68: 295-323.

du Bus de Warnaffe G. and Dufrêne M. 2004. To what extent can management variables explain species assemblages? A study of carabid beetles in forests. Ecography 27: 701-714.

Dufour D. 2003. Etude de l'influence du bois mort sur l'avifaune cavernicole en forêt feuillue. MSc Thesis, University of Gembloux, 67 pp. + Appendices.

Dunk K.v.d., Doczkal D., Röder G., Ssymank A. and MerkelWallner G. 2003. Rote Liste gefährdeter Schwebfliegen (Diptera: Syrphidae) Bayerns. Schr.-R. Bayer. Landesamt f. Umweltschutz 166: 291-298.

Dusek J. and Laska P. 1986. Life cycle strategies in aphidophagous syrphids. In: Hodek I. (ed.), Ecology of Aphidophaga 2. Academia, Praha, pp. 185-192.

Edmonds R.L. and Eglitis A. 1989. The role of the Douglas-fir beetle and wood borers in the decomposition of and nutrient release from Douglas-fir logs. Can. J. For. Res. 19: 853-859.

Ellis W.N. and Ellis-Adam A.C. 1993. To make a meadow it takes a clover and a bee: the entomophilous flora of NW Europe and its insects. Bijdr. Dierkunde 63: 193-220. 
Fayt P., Branquart E., Dufrene M., Henin J.-M., Pontégnie C. and Versteirt V. 2003. Xylobios: patterns, roles and determinants of saproxylic diversity in Belgian deciduous forests. In: McManus L. and Liebhold A.M. (eds), Proceedings of the International Symposium 'Ecology, Survey and Management of Forest Insects'. USDA Forest Service, Delaware, pp. $128-129$.

Franklin J.F., Berg D.R., Thornburgh D.A. and Tappeiner J.C. 1997. Alternative silvicultural approaches to timber harvesting: variable retention harvest systems. In: Kohm K.A. and Franlkin J.F. (eds), Creating a Forestry for the 21st Century. Island Press, Washington, pp. 111-140.

Fuller R.J. and Peterken G.F. 1995. Woodland and scrub. In: Sutherland W.J. and Hill D.A. (eds), Managing Habitats for Conservation. Cambridge University Press, Cambridge, pp. $327-361$.

Gilbert F. 1986. Hoverflies, Naturalists' Handbooks. Cambridge University Press, Cambridge, $66 \mathrm{pp}$.

Gilbert F. and Owen J. 1990. Size, shape, competition, and community structure in hoverflies (Diptera: Syrphidae). J. Anim. Ecol. 59: 21-39.

Good J.A. and Speight M.C.D. 1996. Les invertébrés saproxyliques et leur protection à travers l'Europe. Council of Europe, Strasbourg.

Grove S.J. 2002. Saproxylic insect ecology and the sustainable management of forests. Annu. Rev. Ecol. Syst. 33: 1-23.

Hanks L.M., Millar J.G. and Paine T.D. 1998. Dispersal of the Eucalyptus longhorned borer (Coleoptera: Cerambycidae) in urban landscapes. Env. Ent. 27: 1418-1424.

Härdtle W., von Oheimb G. and Westphal C. 2003. The effects of light and soil conditions on the species richness of the ground vegetation of deciduous forests in northern Germany (Schleswig-Holstein). For. Ecol. Manage. 182: 327-338.

Harmon M.E. and Sexton J. 1996. Guidelines for Measurements of Woody Detritus in Forest Ecosystems. Publication No. 20. U.S. LTER Network, 73 pp.

Harmon M.E., Franklin J.F., Swanson F.J., Sollins P., Gregory S.V., Lattin J.D., Anderson N.H., Cline S.P., Aumen N.G., Sedell J.R., Lienkaemper G.W., Cromack K. Jr. and Cummins K.W. 1986. Ecology of coarse woody debris in temperate ecosystems. Adv. Ecol. Res. 15: 133-302.

Harmon M.E., Sexton J., Caldwell B.A. and Carpenter S.E. 1994. Fungal sporocarp mediated losses of $\mathrm{Ca}, \mathrm{Fe}, \mathrm{K}, \mathrm{Mg}$, $\mathrm{Mn}, \mathrm{N}, \mathrm{P}$, and $\mathrm{Zn}$ from conifer logs in the early stages of decomposition. Can. J. For. Res. 24: 1883-1893.

Haslett J.R. 1989. Adult feeding by holometabolous insects: pollen and nectar as complementary nutrient sources for Rhingia campestris (Diptera: Syrphidae). Oecologia 81: 361-363.

Hunter M.L. 1990. Wildlife, Forests, and Forestry. Prentice Hall, Englewood Cliffs, 370 pp.

Hochbichler E., O'Sullivan A., van Hees A. and Vandekerkhove K. 2000. Working Group 2: recommendations for data collection in forest reserves, with an emphasis on regeneration and strand structure. In: Anonymous (ed.), COST Action E4 Forest Reserves Research Network. European Commission, pp. 135-182.

Hövemeyer K. and Schauermann J. 2003. Succession of Diptera on dead beech wood: a 10-year study. Pedobiol. 47: 61-75.
Irmler U., Heller K. and Warning J. 1996. Age and tree species as factors influencing the populations of insects living in dead wood (Coleoptera, Diptera: Sciaridae, Mycetophilidae). Pedobiol. 40: 134-148.

Jeniš I. 2001. Long-horned beetles. Distenidae, Oxypeltidae, Vesperidae, Anoplodermatidae and Cerambycidae I. Vesperidae and Cerambycidae of Europe I, Atelier Regulus, $333 \mathrm{pp}$.

Kuuluvainen T. 2002. Natural variability of forests as a reference for restoring and managing biological diversity in boreal Fennoscandia. Silva Fennica 36: 97-125.

Lauga J. and Joachim J. 1987. L'échantillonnage des populations d'oiseaux par la méthode des E.F.P.: intérêt d'une étude mathématique de la courbe de richesse cumulée. Acta Oecol./ Oecol. Gener. 8: 117-124.

Lemaire J. 2001. Chênaies wallonnes. État des lieux après un siècle de conversion et perspectives sylvicoles. Forêt Wallonne 53: $20-30$

Martikainen P., Siitonen J., Punttila P., Kaila L. and Rauh J. 2000. Species richness of Coleoptera in mature managed and old-growth boreal forests in southern Finland. Biol. Conserv. 94: 199-209.

Martikainen P. and Kouki J. 2003. Sampling the rarest: threatened beetles in boreal forest biodiversity inventories. Biodiv. Conserv. 12: 1815-1831.

Martin K. and Eadie J.M. 1999. Nest webs: a community-wide approach to the management and conservation of cavitynesting forest birds. For. Ecol. Manage. 115: 243-257.

Mazerolle M.J. and Villard M.-A. 1999. Patch characteristics and landscape context as predictors of species presence and abundance: a review. Ecoscience 6: 117-124.

Millar J.G., Paine T.D., Joyce A.L. and Hanks L.M. 2003. The effects of Eucalyptus pollen on longevity and fecundity of Eucalyptus longhorned borers (Coleoptera: Cerambycidae). J. Econ. Entomol. 96: 370-376.

Muylaert A. 1990. Faune de Belgique. Longicornes (Cerambycidae). Institut Royal des Sciences Naturelles de Belgique, Bruxelles, $139 \mathrm{pp}$.

Nilsson S.G. and Baranowski R. 1997. Habitat predictability and the occurrence of wood beetles in old-growth beech forests. Ecography 20: 491-498.

Økland B., Bakke A., Hågvar S. and Kvamme T. 1996. What factors influence the diversity of saproxylic beetles? A multiscaled study from a spruce forest in southern Norway. Biodiver. Conserv. 5: 75-100.

Owen J. 1981. Trophic variety and abundance of hoverflies (Diptera, Syrphidae) in an English suburban garden. Hol. Ecol. 4: 221-228.

Reemer M. 2005. Saproxylic hoverflies benefit by modern forest management (Diptera: Syrphidae). J. Insect Conserv. 9: 49-59.

Rice W.R. 1989. Analyzing tables of statistical tests. Evolution 43: $223-225$.

Samuelsson J., Gustafsson L. and Ingelög T. 1994. Dying and Dead Trees-a Review of their Importance for Biodiversity. Swedish Threatened Species Unit, Uppsala, Sweden.

Schiegg K. 2000. Effects of dead wood volume and connectivity on saproxylic insect species diversity. Ecoscience 7: 290-298.

Schiegg K. 2001. Saproxylic insect diversity of beech: limbs are richer than trunks. For. Ecol. Manage. 149: 295-304. 
Schmidl J. and Bussler H. 2003. Rote Liste gefährdeter Bockkäfer (Coleoptera: Cerambycidae) Bayerns. Schr.-R. Bayer. Landesamt f. Umweltschutz 166: 150-153.

Shreeve T.G., Dennis R.L.H. and Van Dyck H. 2004 Resources, habitats and metapopulations - whither reality? Oikos 106: 404-408.

Siitonen J. 2001. Forest management, coarse woody debris and saproxylic organisms: Fennoscandian boreal forests as an example. Ecol. Bull. 49: 11-41.

Similä M., Kouki J. and Martikainen P. 2003. Saproxylic beetles in managed and seminatural Scots pine forests: quality of dead wood matters. For. Ecol. Manage. 174: 365-381.

Speight M.C.D. 1989. Saproxylic Invertebrates and Their Conservation. Council of Europe, Strasbourg, 79 pp.

Speight M.C.D. 2000. Some thoughts on corridors and invertebrates: the Hoverfly (Diptera: Syrphidae) fauna of Abies/ Picea forests in temperate West/Central Europe. In: Proceedings of the 'Workshop on the Ecological Corridors for Invertebrates: Strategies of Dispersal and Recolonisation in Today's Agricultural and Forestry Landscapes', Neuchâtél (Switzerland), May 10-12th 2002. Environmental Encounters, No. 45. Council of Europe Publishing, Strasbourg, pp. $116-122$.

Speight M.C.D. 2002. Syrphidae (Diptera) as aids to identification of management priorities in maintenance of biodiversity of forest invertebrates. In: Proceedings of the International Workshop 'Forest Management and Conservation of Saproxylic Invertebrates', Mont Rigi (Belgium), March 11-12th 2002.

Speight M.C.D. and Good J.A. 2003. Development of ecofriendly forestry practices in Europe and the maintenance of saproxylic biodiversity. In: Mason F., Nardi G. and Tisato M. (eds), Proceedings of the International Symposium 'Dead Wood: A Key to Biodiversity', Mantova (Italy), May 29-31st 2003. Sherwood 95(Suppl.), pp. 73-77.

Speight M.C.D., Castella E. and Obrdlik P. 2003a. Macrohabitat preferences of European Syrphidae (Diptera), 2002.
In: Speight M.C.D., Castella E., Obrdlik P. and Ball S. (eds), Syrph the Net, the Database of European Syrphidae 33. Syrph the Net publications, Dublin.

Speight M.C.D., Castella E. and Obrdlik P. 2003b. Microsite features used by European Syrphidae (Diptera), 2002. In: Speight M.C.D., Castella E., Obrdlik P. and Ball S. (eds), Syrph the Net, the database of European Syrphidae 34. Syrph the Net publications, Dublin.

Speight M.C.D., Castella E., Sarthou J.-P. and Monteil C. (eds) 2004. Syrph the Net on CD, Issue 2. The database of European Syrphidae. Syrph the Net publications, Dublin.

Stürken K. 1964. Die Bedeutung der Imaginalernährung für das Reproduktionsvermögen der Syrphiden. Z. Angew. Zool. 51: 385-417.

ter Braak C.J.F. 1988. Partial correspondance analysis. In: Bock H. (ed.), Classification and Related Methods of Data Analysis. Amsterdam, pp. 551-558.

ter Braak C.J.F. and Smilauer P. 1998. Canoco: A Software for Canonical Community Ordination (ver. 4). Centre for Biometry, Wageningen, $351 \mathrm{pp}$.

Verlinden L. and Decleer K. 1987. The hoverflies (Diptera, Syrphidae) of Belgium and their Faunistics: Frequency, Distribution, Phenology. Documents de Travail, no. 39. Institut Royal des Sciences Naturelles de Belgique, Bruxelles, $170 \mathrm{pp}$.

Villiers A. 1978. Faune des coléoptères de France: 1. Cerambycidae. Editions Lechevalier, Paris, 611 pp.

Vockeroth J.R. and Thompson F.C. 1981. Syrphidae. In: McAlpine J.F., Peterson B.V., Shewell G.E., Teskey N.J., Vocxkeroth J.R. and Wood D.M. (eds), Manual of Diptera, Vol. II. Agriculture Canada Monograph 28, pp. 713 743

Warren M.S. and Key R.S. 1991. Woodlands: past, present and potential for insects. In: Collins N.M. and Thomas J.A. (eds), The Conservation of Insects and their Habitats. Fifteenth Symposium of the Royal Entomological Society of London, September 14-15th 1989, pp. 155-211. 